\title{
Role of Media in Consumer Protection
}

\author{
${ }^{1}$ Dr.D.Nabirasool*, ${ }^{2}$ Dr.D.Prabhakar \\ 1 Associate Professor \& Head, MBA Department, Srinivasa Ramanujan Institute of Technology, Anantapur, \\ Andhra Pradesh, INDIA. \\ 2 Assistant Professor, MBA Department, SKIM, SK University, Anantapur, Andhra Pradesh, INDIA.
}

\begin{abstract}
The reach of mass media extends the vast heterogeneous masses of the population of the country at the same time. With the help of mass media messages can be sent and received in any part of the world may be rural or urban. Role of media - print media as well as electronic media can be viewed as awareness of people. The media and non government organizations have an important role to play in the civil society. The media are the among the most important allies to the NGO's community some way in which the media can be important to the NGO's include writing articles / Telecast - Broadcast Programs that :

- Create an environment of political pressure.

- Convey general information, serving as a public education.

- Counter popular misconception.

- Comment on an issue providing an alternative view point.

In this paper more emphasis is given on how media can promote awareness about NGO's activities and also how NGO's need media to convey their message to society and government and also to form public opinion about various policies and lastly media and NGO's can work for betterment of society continuously.
\end{abstract}

Keywords: Consumer, Protection, Media, Education.

\section{Introduction}

Communication is a process to achieve mutual understanding or to have an interaction or exchange of ideas, opinions, facts, information, etc among all human beings or communication is the act of transmitting information, ideas, knowledge from one person to another. Media are viewed as mass media because their reach extends the vast heterogeneous masses of the population of the country at the same time. With the help of mass media messages can be sent and received in any part of the world may be rural or urban.

Role of media- print media as well as electronic media is the awareness of people as well as society has increased enormously. Electronic media has more impact on society as compare to print media because it is visual aid of information. The press in India has always shown its solidarity with the socio economic problems of this country. There are no two opinions about the significantcontribution that press, journalists, and the media people have done goodwork in bringing to light the major issues of socialconcern. The press in India has always been responsive in performing its duties so that those who are involved in the matters of policy making can give justice to their duties. There is no dearth example as to how the press has played a major role in unearthing certain scandalswhere people in the corridors of power were involved. It is not asingular matter for Indian media to take up issues, where a collective action, legislation, and policy decisions was an urgent need. Various legislations, administrative actions and even mass participations from different sections of society with divergent interest were possible only because of initiative and lead taken by media people. May it be a problem of national integration, social unity, and economic injustice, upliftment of down-trodden or educational and economic advancement?

Earlier the readership was the only criteria to assess the affectivity of media, as it was only print media that was its mark. The development of movies brought a big change. People nowcould see and listen what thecommunicator wanted to say? Literacy was no more a criteria to establish a link with audience and viewers.Multiplicities of communicationmedia have brought a sea change in the psychology of people. People becamemore awakened,well-informed and cautious. They could know different views of the same problem; they couldperceive, understand and analyze a situation well. Further advancement of media andmass literacy has alsochanged the composition of our society. Now, people are becomingconscious and logical thinking and rationalbent of mind. The role of media has also broadened. It has undertaken many ventures, along with entertainment,education and enhancement of social structure. Thus, the new media is a mirror of modern society expressing itsneeds, aspirations, expectations and failures. 


\subsection{Meaning and Concept}

\section{Consumer Protection}

Every individual is a consumer, regardless of occupation, age, gender, community orreligious affiliation.Consumer rights and welfare are now an integral part of the life of anindividual and we all have made use of them at some or the other point in our daily routine.

Every year 15th March is observed as "World Consumer Rights Day". It commemorates ahistoric declaration(1962) by former US President John F. Kennedy of four basic consumer rights:

$>$ The right to safety

$>$ The right to be informed

$>$ The right to choose

$>$ The right to be heard

This declaration eventually led to the international recognition of the fact that all citizens, regardless of theirincomes or social standing, have basic rights as consumers. Anothersignificant day is 9 April 1985, when theGeneral Assembly of the United Nations adopted a setof guidelines for consumer protection and the Secretary General of the United Nations wasauthorized to persuade member countries to adopt these guidelines throughpolicy changes orlaw. These guidelines constituted a comprehensive policy framework outlining whatGovernments need to do to promote consumer protection in the following areas:

- Physical safety

- Protection and promotion of consumer economic interests

- Standards for safety and quality of consumer goods and services

- Measures enabling consumers to obtain redressal

- Measures relating to specific areas (food, water, and pharmaceuticals) and

- Consumer education and information program

Now it is universally accepted that the consumer has a right to be provided with all relevantinformation in orderto avoid exploitation and make a considered choice in availing of products and services from the market. Theserights are well-defined, both on international and national platform and several agencies like the Government aswell as voluntary organizations areconstantly working towards safeguarding them.

In India, 24th December is celebrated as"National Consumer Rights Day", since the Consumer Protection Act,1986 was enacted onthis day. The Consumer Protection Act was enacted in 1986 based on United Nationsguidelines with the objective of providing betterprotection of consumers' interests. The Act provides foreffective safeguards to consumersagainst various types of exploitations and unfair dealings, relying on mainlycompensatory rather than a punitive or preventive approach. It applies to all goods and services unlessspecifically exempted and covers the private, public and cooperative sectors and providesfor speedy andinexpensive adjudication.

The rights under the Consumer Protection Act, 1986 flow from the rights enshrined in Articles 14 to 19 of theConstitution of India. The Right toInformation Act (RTI), which has opened up governance processes of ourcountry to the common public also, has far-reaching implications for consumer protection.

As per the Act, a'Consumer' has been defined as:

- Any person who buys goods for consideration, and any person who uses goods with the approval of thepurchaser.

- Any person, who hires any service for a consideration and any beneficiary of such services, provided the service is availed with the approval of the person who had hired the service for a consideration.

Moreover, the consideration for either the goods or services may be either paid or promised, or partly paid or promised, or provided under a system of deferred payment.

The Act envisages the promotion and protection of the following rights of consumers:

\subsection{Right to Safety}

Means right to be protected against the marketing of goods and services, which are hazardous to life and property. The purchased goods and services availed of should notonly meet their immediate needs, but alsofulfill long term interests. Before purchasing,consumers should insist on the quality of the products as well ason the guarantee of the products and services. They should preferably purchase quality marked products such asISI, AGMARK, etc.

\subsection{Right to be Informed}

Means right to be informed about the quality, quantity, potency, purity, standard andprice of goods so as toprotect the consumer against unfair trade practices. Consumer shouldinsist on getting all the information aboutthe product or service before making a choice or adecision. This will enable him to act wisely and responsiblyand also enable him to desist from falling prey to high pressure selling techniques. 


\subsection{Right to Choose}

Means right to be assured, wherever possible of access to variety of goods and services atcompetitive price. Incase of monopolies, it means right to be assured of satisfactory quality andservice at a fair price. It also includes right to basic goods and services. This is becauseunrestricted right of the minority to choose can mean a denialfor the majorityof its fair share.This right can be better exercised in a competitive market wherea variety ofgoods are available at competitive prices.

\subsection{Right to be heard}

Means that consumer's interests will receive due consideration at appropriate forums. It alsoincludes right to berepresented in various forums formed to consider the consumer'swelfare. The consumers should form non-political and non-commercial consumerorganizations which can be given representation in various committeesformed by theGovernment and other bodies in matters relating to consumers.

\subsection{Right to Seek Redressal}

Means right to seek redressal against unfair trade practices or unscrupulous exploitation of consumers. It alsoincludes right to fair settlement of the genuine grievances of theconsumer. Consumers must make complaint fortheir genuine grievances. Many a times theircomplaint may be of small value but its impact on the society as awhole may be very large. They can also take the help of consumer organizations in seeking redressal of their grievances.

\subsection{Right to Consumer Education}

Right to consumer education means the right to acquire the knowledge and skill to be an informed consumerthroughout life. Ignorance of consumers, particularly of ruralconsumers, is mainly responsible for theirexploitation. They should know their rights and must exercise them. Only then real consumer protection can beachieved with success.Thus, the concern of consumer protection is to ensure fair trade practices; quality of goods and efficientserviceswith information to the consumer with regard to quality, quantity, potency,composition and price for theirchoice of purchase. Such a consumer protection policy createsan environment whereby the clients, customers, and consumers receive satisfaction from thedelivery of goods and services needed by them.

\section{Objectives Of The Study}

- To evaluate the response of media towards consumers' cause

- To know, as to what kind of awakening is created by media towards social-evil ofconsumer exploitation.

- To understand how media has come forward to create awareness about consumer protection and all such legislations.

\section{Media And Consumers Problems}

As a general rule, the problem of society, a social group or in some cases, the problems ofindividual are wellexpressed by no one else but media. Our civilization is characterized by impact of media on its structure, value system and outlook. Many socioeconomic problems, education of masses and social awakening can best be done by media. Media presently deals with problems of current importance. Where investigative journalism, reporting of pertinent and important facts and high lightening those events which otherwise cannot be noticedoccupiesprime position. Due to advent of T.V... a large section of society is now influenced by media activities to agreat extent. It has become a silent opinion maker and hence it is working on a larger plane than any otherinstitution. In the current past,media has undertaken the job of consumer education and fighting againstexploitation of consumers.

\section{Research Methodology}

Research process includes research design, which tells about the nature of the study.Research comprisesdefining and redefining problems, and suggested solutions, collection,organizing and evaluating data, making deductions and reaching conclusion. This research is an exploratory research.

\subsection{Sample Design and Sample Size} was 150 .

Random sample procedure was followed to select sample respondents. The total numberof respondents

\subsection{Data Collection Procedure}

Data were collected from the above respondents by using questionnaire specifically designed for the purpose. 


\subsection{Data Collection}

In total 150 questionnaires were distributed out of which 120 sample was finally selected.

\subsection{Analysis of Data}

The statements on consumer awareness were framed after critical review of literature and discussions withexperts in the field. The answer to these statements were sought in terms of 'right', 'wrong', 'not sure' and 'don't know' which were scored as follows :

Right $: 3$ points

Not Sure : 2 points

Wrong : 0 points

Scoring pattern was reverse in case of wrong statements. Thus minimum score was [0] andmaximum possible[105]. Mean and Standard deviation were calculated and range was formed to categorize the respondents asfollows:

Low awareness : $0-35$

Partial awareness : $36-70$

High awareness : :71-105

\section{Data Analysis}

The research has made a survey as to, whether readers refer articles of consumer interest.The major observations in this connection are as follows:-

It was observed from table 1 that out of total 41.6 percent of respondent has lowlevel of awareness regarding consumer terms.

Table 1: Distribution of sample according to their level of consumer awareness $(N=120)$

\begin{tabular}{|c|c|c|c|c|c|c|}
\hline \multirow{2}{*}{ Respondents } & \multicolumn{2}{|c|}{ Low } & \multicolumn{2}{c|}{ Partial } & \multicolumn{2}{c|}{ High } \\
\cline { 2 - 7 } & Frequency & \%age & Frequency & \%age & Frequency & \%age \\
\hline $18-25$ & 15 & 12.45 & 06 & 4.98 & 04 & 3.32 \\
\hline $26-33$ & 11 & 9.13 & 07 & 5.81 & 03 & 2.49 \\
\hline $34-41$ & 10 & 8.30 & 03 & 2.49 & 05 & 4.15 \\
\hline $42-49$ & 06 & 4.98 & 05 & 4.15 & 07 & 5.81 \\
\hline $50-57$ & 05 & 4.15 & 04 & 3.32 & 10 & 8.30 \\
\hline $58-65$ & 03 & 2.49 & 03 & 2.49 & 13 & 10.79 \\
\hline & 50 & 41.6 & 28 & 23.3 & 42 & 35.0 \\
\hline
\end{tabular}

\section{Result}

- There is a significant difference between the awareness levels of the respondent of different age groupregarding consumer protection law. Respondent above the age groupof 50 were more aware about thepopular consumer terminology than the respondent below the age group of 49 .

- Television was the main media which influence their buying most.

- There is a significant difference between the awareness levels of the respondent of different age group about consumer organization working in and around their area. Respondent above the age group of 42 weremore aware about the consumer organization working in theirarea than the respondent below the age groupof 41 .

\section{Discussion}

The research has made a survey as to, whether readers refer articles of consumer interest. The major observations in this connection are as follows:

- A majority of consumers read the articles regarding consumers' interest. However, the frequency of reading these articles on a regular basis is not very high

- The readership of these articles is limited and irregular which indicates that, there is a limitedand lukewarminterest in the issues of consumer concern.

- The expectation of consumers in connection with consumers' column varies. However,most of theconsumers prefer to read matters regarding consumers' interest and legaldecisions and Governmentpolicies affecting consumers' interest. This indicates apurposive and limited interest of readers in the consumers' movement.

- There is a general disinterest to read about issues related with consumer movement and activities of the local consumers' associations.

- Most of the consumers feel that these articles do help them to know about consumers, right and about consumer movement. 


\section{Conclusions}

Media in all its form, print or electronic, is a mirror of the times and society we live in. It connects us to the world and the world to us. Media is an integral part of our life. Intoday's world, where one's social circle ismostly just worked related, based on some or theother selfish motive, we tend to believe and depend more onthe media for every type ofinformation. Media thus has tremendous impact on the way a society conducts itselfin thepresent, as well as the shape it would take in the future. It influences people of all age group.Media alsoplays a very useful role in setting up good or amicable relations between traders and buyers. The promotions of fair trade practices, establishing code of conduct for businessmen are the task that media alone can shoulder. The concept of ethics in the economy relates to "morality, ethics, professional and organizational ethics. Each industry has its ownguidelines for the ethical requirements. But on the four main requirements for marketing communications are legal, decent, honest and truthful. Unfortunately, in a society that is the way the company intended to profit from the use of marketing communication messages targets "can be a form of social pollution from potentially harmful and unintended effects of the consumer may have the decision represented". The words of Bernstein (1951), said fifty-six years ago are still very much a question of present interest: 'It is not true that if we 'save advertising, we save all,' but it seems reasonable to assume that if we do not save advertising, we might lose all."

\section{Future Scope}

There is a wide scope for further research since this study was limited to the role of media in consumer education and protection, but the arrival of e-commerce, m-commerce, and Right to Information Act 2005which was passed by Indian Parliament by June 15, 2005 and came fully into force on October 13, 2005. Future research can focus on the study of the Indian consumer who are now enable to college, share, compile and analyze the information in certain cases such as fairness, values and ethics within the buying and selling in India.

\section{References}

[1] Parmeshwar, K.R.: Protect Consumer against quality tricksters. Yojna 32 (5) (1988)

[2] http://commerceweaverpro.com/role-of-media-in-consumer-protection.html

[3] http://commerceweaverpro.com/role-of-media-in-consumer-protection.html

[4] http://consumereducation.in/

[5] http://consumergoods.indiabizclub.com/info/consumer_rights

[6] http://www.consumer.tn.gov.in

[7] http://www.consumerdaddy.com 